\title{
Vertical swimming behavior influences the dispersal of simulated oyster larvae in a coupled particle-tracking and hydrodynamic model of Chesapeake Bay
}

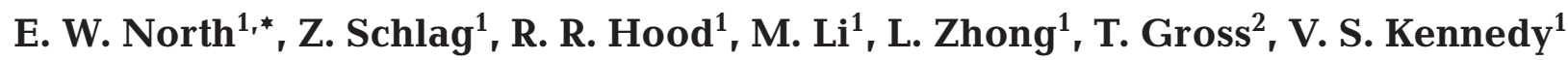 \\ ${ }^{1}$ University of Maryland Center for Environmental Science, Horn Point Laboratory, 2020 Horns Point Road, \\ Cambridge, Maryland 21613, USA
}

${ }^{2}$ NOAA/NOS and Chesapeake Research Consortium, 645 Contees Wharf Road, Edgewater, Maryland 21037, USA

\begin{abstract}
Because planktonic organisms have swimming speeds that are orders of magnitude lower than horizontal current velocities, it is unclear whether behavior of weak-swimming bivalve larvae could influence dispersal distance, encounters with suitable habitat, or subpopulation connectivity. We used a numerical approach to investigate whether these processes could be affected by species-specific differences in larval vertical swimming behavior of 2 oyster species (Crassostrea virginica and C. ariakensis) in Chesapeake Bay, a partially mixed estuary. A coupled particle-tracking and hydrodynamic model was forced with observed winds and freshwater flow and included the best available estimate of present-day oyster habitat. Model scenarios were conducted with hydrodynamic predictions from June to September, 1995 to 1999, to simulate a range of environmental conditions. Simple larval swimming behaviors were parameterized for the 2 oyster species with results from preliminary laboratory experiments and literature. To isolate the effect of circulation, settlement habitat, and larval behavior on the spatial trajectories of particles, vertical swimming velocity was the only biological process represented in the model; egg production and larval growth were not included. Differences in larval swimming behavior had significant consequences for particle transport in Chesapeake Bay by influencing dispersal distances, transport success, and the degree of connectivity between 'subpopulations' in different tributaries. Most particles (>96\%) did not return to the same reef on which they were released, and there were behavior-dependent differences in spatial patterns of the 'source' and 'sink' characteristics of oyster reefs. Simulated larval behavior had greater influence on spatial patterns of transport success than did interannual differences in circulation patterns. These model results have implications for fisheries management and oyster restoration activities.
\end{abstract}

KEY WORDS: Connectivity · Coupled bio-physical model · Crassostrea virginica · Crassostrea ariakensis · Larval transport · Larval swimming behavior · Larval dispersal · Particle-tracking model

\section{INTRODUCTION}

Despite the weak swimming abilities of planktonic invertebrates ( 1 to $10 \mathrm{~mm} \mathrm{~s}^{-1}$ ) compared to horizontal current velocities $\left(>1 \mathrm{~m} \mathrm{~s}^{-1}\right)$, recent field and numerical evidence indicates that swimming behavior can influence the direction and intensity of plankter transport and dispersal (Genin et al. 2005, Shanks \& Brink 2005, Batchelder 2006, Knights et al. 2006). Although application of numerical tools to investigate dispersal of Caribbean fish larvae indicates that swimming behavior could influence dispersal and population connectivity (Cowen et al. 2006), swimming speeds of tropical fish larvae (Leis 2007) are an order of magnitude 
greater than those of oyster larvae (Kennedy 1996). Our objective was to determine if species-specific differences in larval swimming behavior could influence spatial patterns of dispersal in 2 oyster species (Crassostrea virginica and C. ariakensis) in Chesapeake Bay.

Chesapeake Bay is a large ( $320 \mathrm{~km}$ long), partially mixed estuary with a persistent halocline and predominantly 2-layer circulation patterns driven primarily by river inflow (Pritchard 1952, Wang 1979). The greatest proportion of its freshwater input originates from the Susquehanna $(48 \%)$, Potomac $(14 \%)$, James $(13 \%)$, Rappahannock (3\%), Choptank $(1 \%)$ and York $(1 \%)$ Rivers (Schubel \& Pritchard 1987). River inflow influences salinity distributions, which in turn affect the distribution of oysters: Adults are generally found in salinities $>5$ and depths $<10 \mathrm{~m}$ throughout the Chesapeake Bay and tributaries (Kennedy 1991). In addition to river flow, the Chesapeake mainstem and tributaries are forced by tides $(0.3$ to $0.9 \mathrm{~m}$ tidal amplitude; Schubel \& Pritchard 1987, Zhong \& Li 2006) and by winds that act both locally and remotely (Boicourt 1992, L. Zhong, M. Li, M. G. G. Foreman unpubl.).

Although Crassostrea virginica is native to Chesapeake Bay, abundances have declined nearly 100 -fold due to overharvesting, disease, and habitat loss over the last century (Rothschild et al. 1994, Jordan et al. 2002). Oyster restoration is a goal of state and federal agencies, with the objectives of supporting the commercial harvest and enhancing the ecosystem services provided by oysters though filtration and reef structure (Chesapeake Bay Program 2000, USACOE 2004). Our purpose was to assess whether population dispersal would be similar between restored populations of $C$. virginica and the non-native $C$. ariakensis proposed for introduction to Chesapeake Bay (USACOE 2004). Preliminary results of laboratory studies suggested that larval swimming behavior of the 2 oyster species differed. Newell et al. (2005) reported complex behavior for broods of larvae reared from adult C. virginica obtained from Chesapeake Bay and $C$. ariakensis bred from the 'west coast stock' (Breese \& Malouf 1977). One apparent difference was that $C$. virginica tended to swim higher in the water column whereas C. ariakensis tended to be found lower in the water column. Such differences were especially noticeable when larvae encountered a halocline within the experimental system. Although larval behaviors of these species were more complex than a simple response to a halocline (Newell et al. 2005, J. L. Manuel et al. unpubl.), the goal of this numerical study was to determine whether this simple difference in larval behavior could influence dispersal of oyster larvae and their encounter with suitable settlement habitat in Chesapeake Bay.

\section{MATERIALS AND METHODS}

We constructed a larval transport model that incorporated predictions from a hydrodynamic model and a particle-tracking model to calculate the movement of particles that simulate oyster larvae. The model tracked the trajectories of oyster larvae in 3 dimensions and predicted settlement locations on specific oyster reefs. It was forced with observed river flow and wind conditions to capture a range of environmental variability experienced by oyster larvae. It did not include biological processes (production, growth, mortality) that are well articulated in 1 and 2D individually based models of oyster larvae (e.g. Dekshenieks et al. 1997, Hofmann et al. 2004). Instead of focusing on biological processes like egg production, larval growth, and predation mortality, we isolated the influence of physical conditions and organism behavior on the 3D spatial trajectories of particles to determine if larval swimming behavior could influence dispersal distance, encounter with suitable habitat, and subpopulation connectivity.

The larval transport model was created by linking a hydrodynamic and a particle-tracking model, and including behavior and settlement sub-models. Model scenarios were conducted with different larval swimming behaviors and with environmental forcing based on 5 years of data (1995 to 1999) to simulate a range of physical conditions.

\section{A. Hydrodynamic model}

We employed the Regional Ocean Modeling System (ROMS), a free-surface, hydrostatic, primitive equation ocean model that uses stretched, terrain-following coordinates in the vertical direction, and orthogonal curvilinear coordinates in the horizontal direction (Song \& Haidvogel 1994). The ROMS Chesapeake Bay implementation (Li et al. 2005) had a horizontal grid spacing of $\sim 1 \mathrm{~km}$ and 20 vertical layers (Fig. 1). It was forced by open ocean tides, freshwater flow at river heads, winds, and heat exchange across the water surface. At the upstream boundaries of 8 major tributaries, daily freshwater flow with zero salinity and time-varying temperature were prescribed. The vertical eddy viscosity and diffusivity were computed using turbulence mixing schemes (Warner et al. 2005), and coefficients of horizontal eddy viscosity and diffusivity were set to $1 \mathrm{~m}^{2} \mathrm{~s}^{-1}$. The model has been validated against a wide variety of observational data, including (1) sealevel records at tidal gauge stations, (2) tidal current measurements, (3) long-term salinity and temperature time series at the monitoring stations maintained by the Chesapeake Bay Program (EPA CBP, www. chesapeakebay.net/data/index.htm), (4) real-time cur- 
rent velocity measurements at the buoys of Chesapeake Bay Observing System (CBOS), and (5) 3D synoptic salinity maps (along-channel and cross-channel sections) from undulating CTD surveys (Li et al. 2005, Zhong \& Li 2006). The hydrodynamic model accurately predicts tidal elevation, tidal and subtidal currents, and temperature and salinity distributions in Chesapeake Bay and simulates estuarine dynamics ranging from annual time scales to the episodic event time scale of hurricanes (Li et al. 2006, 2007). In addition, sea level predictions in tributaries are robust (Zhong \& Li 2006).

To capture a range of physical conditions that could influence oyster larvae dispersal, the hydrodynamic model was run with wind and freshwater flow measured from 1995 to 1999. This sequence of years included high, low, and average freshwater flow conditions (Table 1). Hourly wind stress was linearly interpolated from 3 stations (Norfolk International Airport, Patuxent River Naval Station, and Baltimore-Washington International Airport) from 1995 to 1997 or 2 stations (Chesapeake Bay Bridge Tunnel and Thomas Point Light) from 1998 to 1999. The model was run with forcing conditions from 1994 to 'spin up' the model in preparation for the 1995 to 1999 simulations. Validation metrics from a comparison between Chesapeake Bay salinity observations and model predictions from May to September 1995 to 1999 indicated good predictive ability: Root-mean-square errors were between 1.9 and 2.7 and model skill scores (Warner et al. 2005) were between 0.85 and 0.89 in tributaries and between 0.93 and 0.95 in the mainstem (North et al. 2006b).

\section{B. Particle-tracking model}

The larval transport model (LTRANS) was based on a particle-tracking model and was designed to predict the movement of particles based on advection, subgrid scale turbulence, and larval swimming behavior. It included an external time step - the time step of hydrodynamic model output (10 min), and an internal time step - the time interval of particle movement (120 s).

Because the hydrodynamic model has a horizontal resolution of $1 \mathrm{~km}$, it may take many time steps for a particle to move across a grid cell. Hence the predicted salinity, currents $\left(\mathrm{m} \mathrm{s}^{-1}\right)$, and other hydrodynamic quantities were interpolated in both space and time to provide a fine-resolution velocity field for advecting oyster larvae. Twodimensional water properties were interpolated in space to the particle location using bilinear interpolation (sea surface height, water depth). For 3D

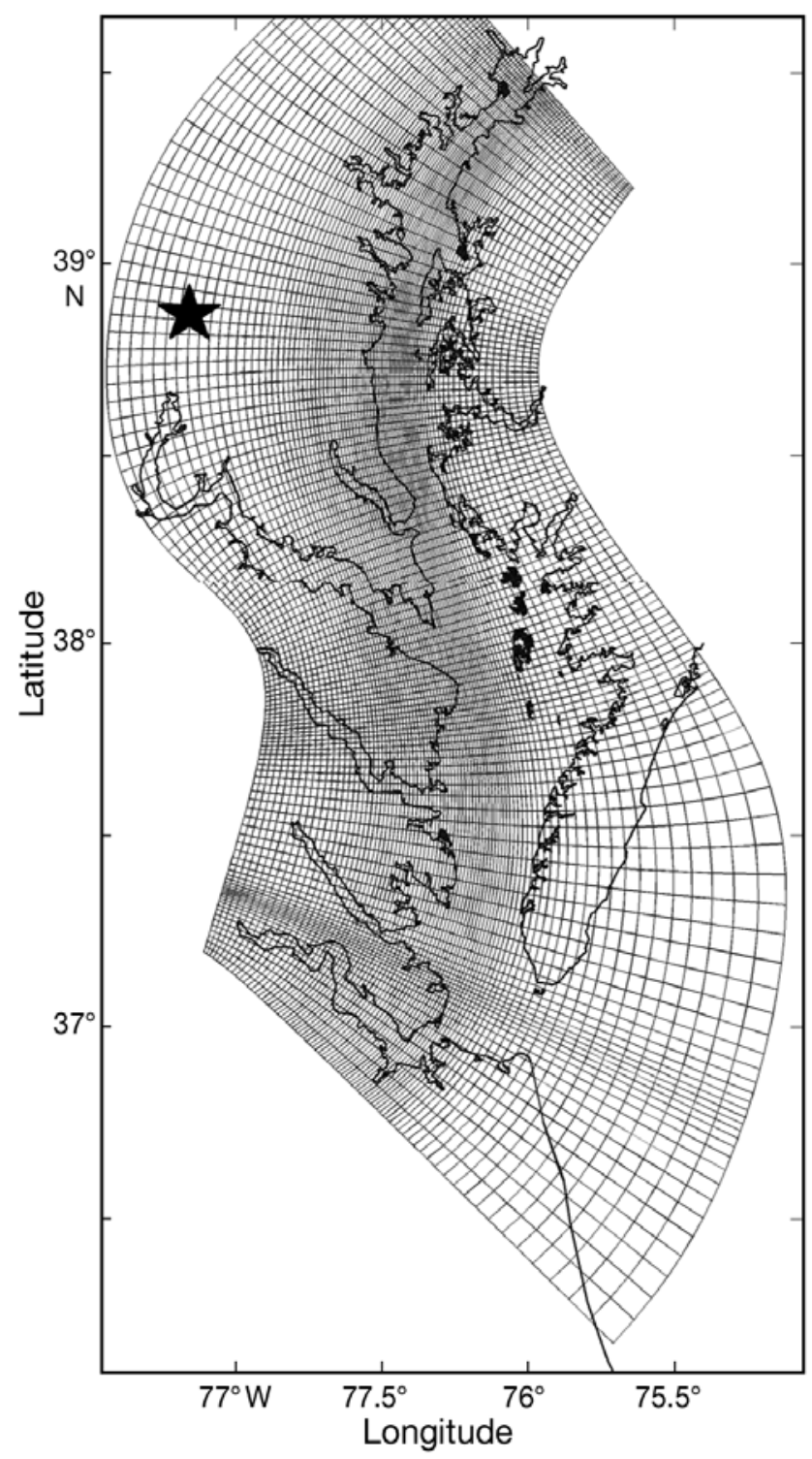

Fig. 1. Chesapeake Bay shoreline (black) and ROMS hydrodynamic model grid (gray). Star indicates location of Washington, DC, USA

Table 1. Dates of 5 releases of particles during each year for Crassostrea virginica and $C$. ariakensis larval transport simulations, and observed freshwater discharge into Chesapeake during the main time period of larval transport (June to August). For comparison, the 48 yr mean (1952 to 2000) was $3637 \mathrm{~m}^{3} \mathrm{~s}^{-1}$ and the 25 th and 75 th percentile values were 2424 and $4279 \mathrm{~m}^{3} \mathrm{~s}^{-1}$, respectively. Streamflow data from USGS (http://md.water.usgs.gov)

\begin{tabular}{|crrrrrr|}
\hline \multirow{2}{*}{ Year } & \multicolumn{4}{c}{ Particle release date } & \multicolumn{2}{c|}{ Freshwater } \\
& \multicolumn{1}{c}{ I } & II & III & IV & V & flow $\left(\mathrm{m}^{3} \mathrm{~s}^{-1}\right)$ \\
\hline 1995 & June 23 & June 29 & July 5 & July 30 & August 5 & 4480 \\
1996 & June 30 & July 6 & July 12 & August 6 & August 12 & 5607 \\
1997 & July 11 & July 17 & July 23 & August 2 & August 17 & 3007 \\
1998 & June 20 & June 26 & July 2 & July 23 & August 2 & 3392 \\
1999 & June 20 & June 26 & July 2 & July 23 & August 2 & 1249 \\
\hline
\end{tabular}


water properties (current velocities, diffusivities, salinity), a water-column profile scheme (North et al. 2006a) was applied with bilinear interpolation along s-levels in the $\mathrm{x}$ and $\mathrm{y}$ directions and a tension spline in the $\mathrm{z}$ direction. A polynomial fit was used to interpolate water properties in time. For particle movement due to current velocities in the $\mathrm{x}, \mathrm{y}$, and $\mathrm{z}$ directions, a 4th order Runge-Kutta scheme was implemented. The 4 th order Runge-Kutta scheme provides the most robust estimate of the trajectory of particle motion in water bodies with complex fronts and eddy fields (Dippner 2004) like Chesapeake Bay. A logarithmic reduction in current velocities (i.e. law-of-the-wall) was applied within one s-level of bottom to simulate reduction in current velocities near bottom due to friction (North et al. 2006a).

A random displacement model (Hunter et al. 1993, Visser 1997) was implemented within the larval transport model to simulate sub-grid scale turbulent particle motion in the vertical ( $\mathrm{z}$ ) direction following Visser (1997). A smoothing algorithm was applied to the water column profile of vertical diffusivity $\left(\mathrm{m}^{2} \mathrm{~s}^{-1}\right)$ to prevent artificial aggregation of particles in regions of sharp gradients in diffusivity and to satisfy the well-mixed criterion (North et al. 2006a). The 4th order Runge-Kutta was applied in time but not in space due to computational constraints associated with the short time step $(2 \mathrm{~s})$ of the random displacement model. Vertical diffusivities at the surface and bottom were set to 0 . Because horizontal diffusivity was constant in the hydrodynamic model $\left(1 \mathrm{~m}^{2}\right.$ $\mathrm{s}^{-1}$ ), a random walk model was used to simulate turbulent particle motion in the horizontal direction.

Boundary conditions were imposed. If a particle passed through the surface or bottom boundary due to turbulence or vertical advection, the particle was placed back in the model domain at a distance that was equal to the distance that the particle exceeded the boundary (i.e. it was reflected vertically). If a particle passed through the surface or bottom due to particle behavior, the particle was placed just below the surface or above the bottom (i.e. it stopped near the boundary). If a particle intersected a horizontal boundary, the particle was reflected off the boundary at an angle of reflection that equaled the angle of approach to the boundary.

\section{Behavior sub-model}

The behavior sub-model was parameterized with larval swimming behaviors discerned from laboratory studies and inferred from field observations, as referenced below. It is a simplification of the complex species-specific behaviors of Crassostrea virginica and C. ariakensis (Newell et al. 2005, J. L. Manuel, R. I. E. Newell, V. S. Kennedy unpubl.). Throughout our paper, simulated larvae are referred to as 'particles' to clearly distinguish simulated species from the reality of complex living organisms, and to remind the reader that each particle trajectory represents the path of hundreds of thousands of larvae because a single oyster could spawn more eggs than all of the particles that we were able to track in this analysis due to computational constraints. The behavior model included swimming speed $\left(\mathrm{mm} \mathrm{s}^{-1}\right)$ and behavioral cue components that regulated the vertical velocity of particle movement. It was developed as a stand-alone, 1D model (Fig. 2) before being incorporated in the 3D coupled bio-physical model.

Particle stage durations were randomly assigned to mimic individual variation in oyster larvae using information on Crassostrea virginica from Carriker (1996), Kennedy (1996), Shumway (1996), and Thompson et al. (1996). Each particle was assigned an age at which it becomes a pediveliger (when it would be competent

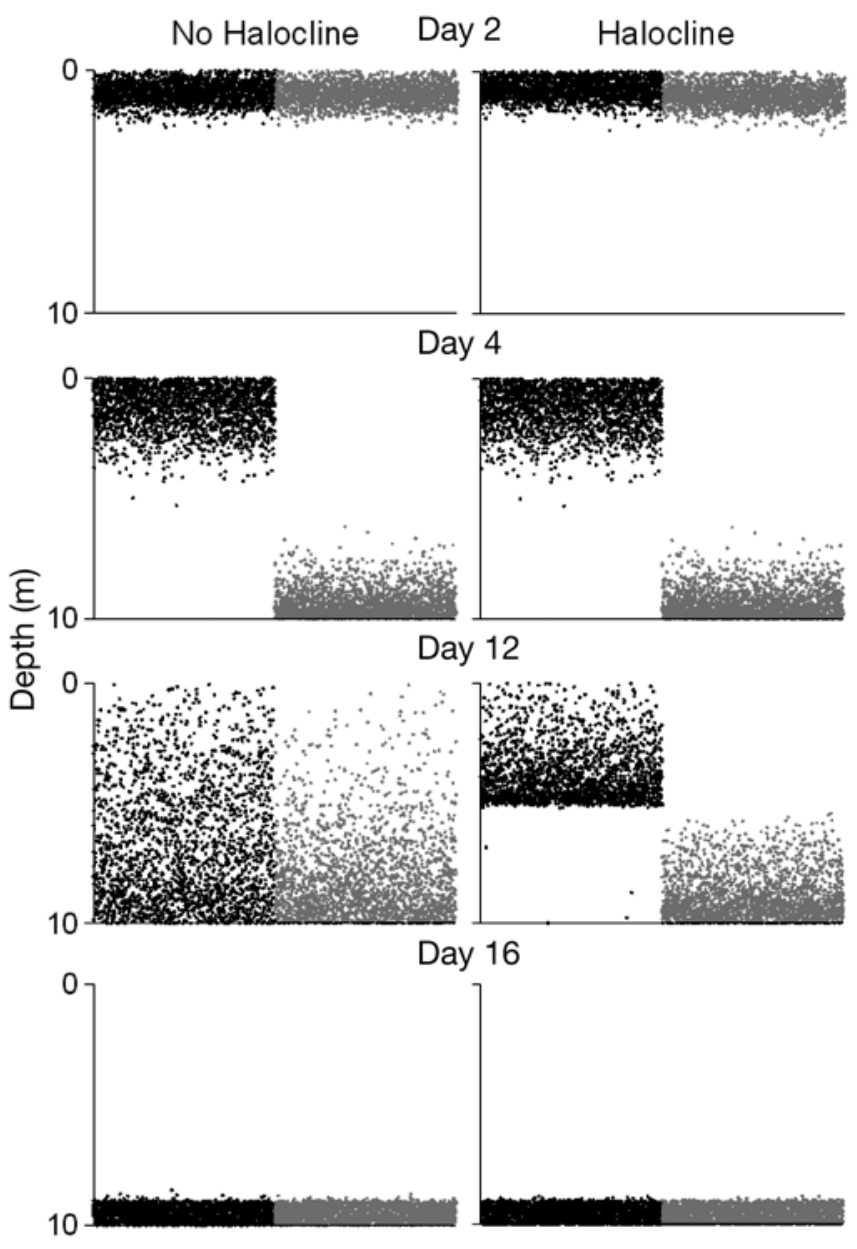

Fig. 2. Selected snapshots of 1D model predictions of the depth distribution of Crassostrea virginica particles (black), and $C$. ariakensis particles (gray) over time in the absence (left panels) or presence (right panels) of a halocline. The time of the snapshots is indicated between the panels 
to settle) and an age at which it was assumed that it would no longer be competent to settle, whereupon it would die. Because ages vary among individual oyster larvae, a random number generator was used to assign ages in a normal distribution around $14 \mathrm{~d}$ (for the age at which transition to pediveliger occurs) and $21 \mathrm{~d}$ (age at which particles were no longer competent to settle). Resulting mean veliger and pediveliger stage durations were 13.5 and $7 \mathrm{~d}$, respectively. Crassostrea virginica and $C$. ariakensis particles were assigned the same stage durations.

Swimming speeds of Crassostrea virginica and $C$. ariakensis larvae vary from 0 to $\sim 3.0 \mathrm{~mm} \mathrm{~s}^{-1}$ as larvae develop from fertilized eggs to pediveligers (Mann \& Rainer 1990, Kennedy 1996, Newell et al. 2005, J. L. Manuel et al. unpubl.). The swimming speed of a particle was determined by its age. Particles that were 0 to $0.5 \mathrm{~d}$ old were assumed to be fertilized gametes and early trochophores that did not swim. From Day 0.5 to the end of the veliger stage, maximum swimming speed increased linearly from 0.5 to $3 \mathrm{~mm} \mathrm{~s}^{-1}$. The maximum swimming speed was multiplied by a number drawn from a uniform random distribution between 0 and 1 to simulate random variation in the movements of individual oyster larvae. During the pediveliger stage, the swimming speed was $3.0 \mathrm{~mm} \mathrm{~s}^{-1}$ and no random component was added (although there was a random component to the direction of motion as explained below).

The vertical direction of particle movement was regulated by the behavioral cue component. Preliminary analysis of laboratory studies (Newell et al. 2005) indicated that Crassostrea virginica larvae generally swam up in the presence of a halocline whereas C. ariakensis larvae swam down and remained near bottom. Laboratory results of Hidu \& Haskin (1978) also indicated that C. virginica oyster larvae changed swimming behavior in response to salinity gradients. Simulated behavioral motion was limited to the vertical direction and was considered an integration of the helical swimming patterns of oyster larvae and observed swimming and sinking behaviors (Kennedy 1996).

The direction of particle motion was assigned a random component that was weighted so particles would have a tendency to move up or down depending on species and age of particle (Fig. 2). In the late trochophore and early veliger stage (0.5 to $1.5 \mathrm{~d})$, particles of both species swam up to simulate the initial near-surface distribution of larvae observed in the laboratory (V. S. Kennedy pers. obs.). Once in the veliger stage, the swimming behaviors differed between species and in the presence or absence of a halocline. In the absence of a halocline (i.e. in well-mixed conditions), Crassostrea virginica veliger-stage particle distributions shifted deeper as they increased in age, as has been observed (Andrews 1983, Baker 2003) and modeled in previous studies (Dekshenieks et al. 1996). Swimming directions of $C$. ariakensis veliger-stage particles in the absence of a halocline simulated weakly bottom-oriented distributions (Fig. 2) as observed in the laboratory (Newell et al. 2005).

In the presence of a halocline, the veliger-stage particles of the 2 species responded differently to the same salinity cue. The presence of a halocline was determined by the change in the vertical gradient in salinity $\Delta S$ experienced by the particle and was a function of salinity at the particle location $(s)$, depth of particle $(z)$, and time step $(t)$ :

$$
\Delta S=\frac{\left(s_{t-1}-s_{t}\right)}{\left(z_{t-1}-z_{t}\right)}
$$

If the gradient in salinity was greater than a threshold value, then Crassostrea virginica veliger-stage particles were cued to swim upward in that time step. The threshold value $\Delta S_{\text {threshold }}$ was set as 1.0 salinity unit $\mathrm{m}^{-1}$, the mean of maximum salinity gradients predicted by the hydrodynamic model on July 1, 1995 in mainstem Chesapeake Bay (the region where maximum salinity gradients were expected to occur). This non-biologically based technique for setting the threshold was employed because (1) laboratory experiments that were used to parameterize larval swimming behavior (Newell et al. 2005) did not test behavior in response to in situ gradients in salinity (technical constraints limited salinity gradients to higher gradients than found in Chesapeake Bay), and (2) the salinity gradients predicted by the hydrodynamic model were lower than observed in Chesapeake Bay, dictating the need to scale the threshold value to hydrodynamic model predictions. The salinity-gradient response, combined with the slight bottom-oriented shift as particles increased in age, resulted in aggregation of veliger-stage particles above the halocline (Fig. 2). Such aggregations have been observed in field studies of $C$. virginica (Nelson \& Perkins 1932, Carriker 1951) and other bivalve species (Mann et al. 1991). If C. ariakensis veligerstage particles detected a salinity gradient, they were cued to swim down until they were within $1 \mathrm{~m}$ of bottom or for $2 \mathrm{~h}$, whichever came first. This simulated the strong bottom-oriented behavior of $C$. ariakensis in the presence of a halocline reported by Newell et al. (2005).

Pediveliger-age particles of both species had the same swimming behavior: They swam down unless they were within $1 \mathrm{~m}$ of bottom (Fig. 2). Within $1 \mathrm{~m}$ of bottom, pediveliger particles had randomly directed motions. Particles remained in the pediveliger stage until they either encountered a simulated oyster reef or reached the age at which they were no longer competent to settle (i.e. they died). 


\section{Settlement sub-model}

The purpose of the settlement sub-model was to determine if a pediveliger-stage particle encountered suitable habitat. In Maryland waters, suitable habitat was based on the 'cultch' (i.e. oyster shell) GIS-layer polygons from the Maryland Bay Bottom Survey conducted in the late-1970s and 1980. Since the 1980s, the area of oyster habitat in Maryland's Choptank River has been greatly reduced (Smith et al. 2005). For the larval transport model, the cultch-layer polygons in Maryland waters were correspondingly reduced to $29.2 \%$ of their original area, but their shape and centroid (center location) were retained (Greenhawk 2005). In Virginia waters, oyster habitat included polygons for both public and leased bottom that were based on bottom surveys in the 1990s. Oyster reefs outside the boundaries of the hydrodynamic model were not included. Each cultch polygon in the model domain simulated a separate oyster reef (2776 total 'bars') (Fig. 3) and was assigned a unique bar identification

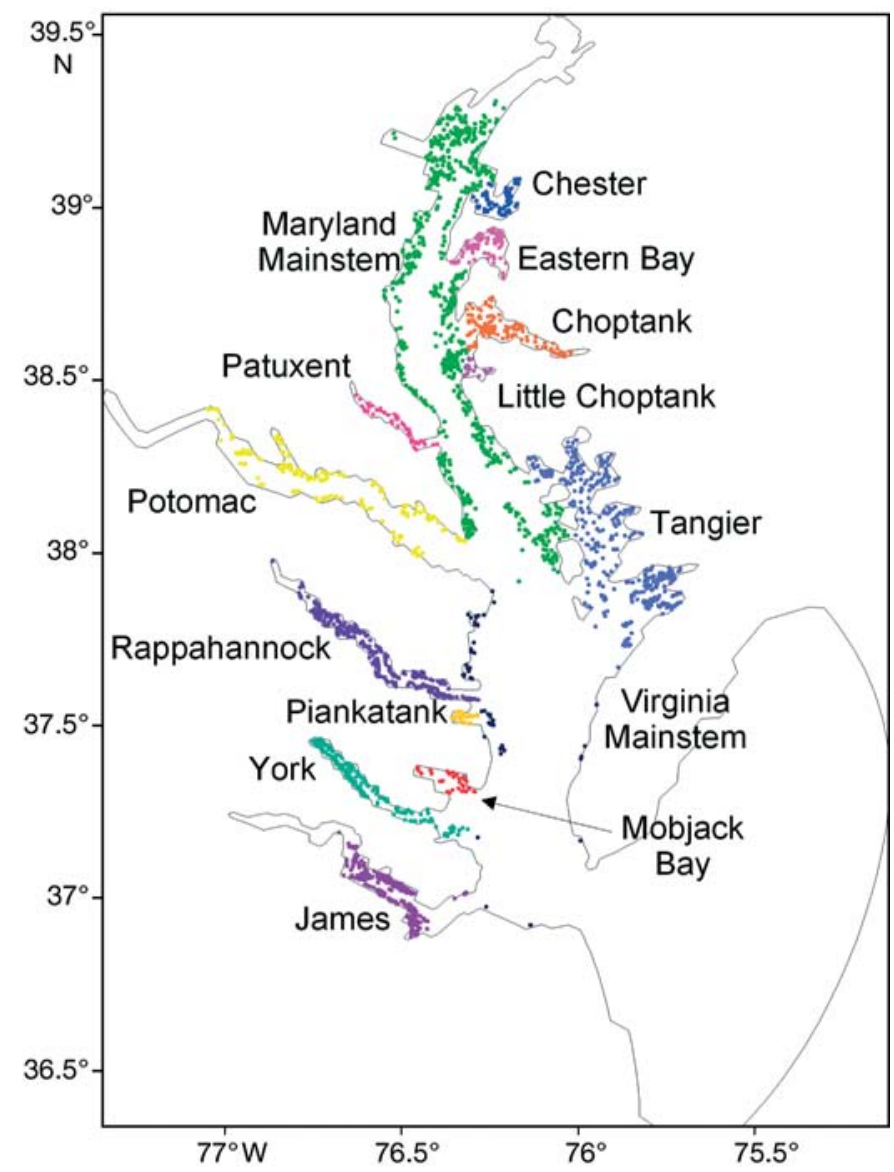

Fig. 3. Boundaries of the larval transport model (gray lines) and oyster bars (i.e. habitat polygons) color coded by basin. Particles were released from the center of each of the 2776 oyster bars number. For every internal time step (120 s), each pediveliger-stage particle was tested to determine if it was within the boundaries of an oyster bar. If it was, then encounter with suitable habitat occurred and the particle stopped moving.

Two major simplifications were implicit in the settlement sub-model. First, particles within the polygon boundaries were considered successful regardless of their height above bottom. Little evidence exists to guide model parameterization in a 3D context, although a flume study indicated that Crassostrea virginica pediveligers could display a 'dive-bombing' behavior in a $5 \mathrm{~cm}$-deep flume (Finelli \& Wethey 2003). The second simplification in the model was that cultch was the only substrate on which $C$. virginica and $C$. ariakensis oyster larvae could settle. Although both species have settled on granite and PVC, oyster shell is a preferred substrate (Luckenbach et al. 2005) and chemical cues from living oysters promote $C$. virginica larval settlement (Turner et al. 1994, Tamburri et al. 1996).

\section{E. Scenarios}

To simulate pulses in spawning and settlement, 5 releases of 62773 particles were conducted for each year (1569325 particles total for each species) during the time when peak spawning of Crassostrea virginica occurs in Chesapeake Bay (June to August) (Table 1). Particles were released from the center of each cultch polygon in numbers that were proportional to the area of each polygon (10 particles acre ${ }^{-1}$ or 10 particles for polygons $<1$ acre; 1 acre $=0.40$ ha).

Particle release began each year on the day on which mean water temperatures reached $25^{\circ} \mathrm{C}$ in Chesapeake Bay (reports of the lower mass spawning temperature for Crassostrea virginica in Chesapeake Bay were on average $\sim 25^{\circ} \mathrm{C}$; summarized by Shumway 1996). A polynomial curve was fit to the data from Chesapeake Bay Program monitoring stations in the Chesapeake Bay and tributaries (www.chesapeakebay. net/data/) to estimate the day on which temperatures reached $25^{\circ} \mathrm{C}$ in each year (North et al. 2006b). After the first release of particles, the timing of releases was chosen so that particles would settle in 2 peaks roughly 1 mo apart. Two peaks in $C$. virginica larval settlement have been observed in Chesapeake Bay (Kennedy 1996, Southworth et al. 2003 and reports referenced therein), although not in every tributary and every year. Particle settlement occurred between July 1 and September 15. This settlement window corresponded with the timing of the bulk of $C$. virginica larval settlement in Chesapeake Bay (Kennedy 1996, Southworth et al. 2003 and reports referenced therein; 
see North et al. 2006b for more details). Due to lack of information regarding $C$. ariakensis in their natural habitat, the $C$. ariakensis release days were the same as $C$. virginica release days. This permitted direct comparison of the influence of swimming behavior on larval transport because the only difference between the models of the 2 species was larval swimming behavior.

\section{F. Analysis}

Model predictions were analyzed to determine if differences in larval swimming behavior influenced temporal and spatial patterns in particle dispersal distance, transport success, and connectivity between basins. Simulated oyster bars were assigned to basins that corresponded with Crassostrea virginica management classifications in Chesapeake Bay (Fig. 3).

Dispersal distance. Dispersal distance of particles was used to quantify the distance that particles traveled between release and settlement along the shortest path within model boundaries. It was calculated for particles that encountered suitable habitat (i.e. 'successful' particles).

Transport success. Percent transport success was calculated as the number of particles that encountered an oyster bar per number of particles released, either from the entire Bay, from each basin, or from each bar. Transport success scores were analyzed for evidence of self-recruitment, the transport source-sink characteristics of individual bars, and potential connectivity between basins. Self-recruitment was quantified as the percent of particles that encountered the same bar from which they were released per number of particles released from that bar. For each bar, the 'source' metric was calculated as the percent of particles that were released from the bar and encountered a bar (anywhere) per number of particles released from the origin bar. The 'sink' metric was estimated as the percent of particles that encountered the bar per number of particles that were released from that bar and encountered a bar (anywhere). [The transport source-sink metrics differ from standard ecological source-sink definitions (Pulliam 1988) because they do not include egg production by adults and mortality.] Connectivity was calculated as the proportion of particles that were released within one basin and encountered bars in other basins or in the basin in which they started.

Analysis of variance tests were conducted to determine if basin-specific median dispersal distances and transport success scores differed between species, basins, and years (PROC MIXED, SAS ver 9.1). Multiple regression analyses were conducted for each species to determine if a significant amount of the variability in basin-specific median dispersal distance and transport success was described by wind strength (mean of the summed magnitudes in the east and north directions in each basin), freshwater flow (mean freshwater discharge into basins with freshwater forcing), and habitat coverage (the summed area of oyster bars in each basin divided by the total area of the basin) (PROC MIXED, SAS ver 9.1). For all tests, dispersal distances were ln-transformed and transport success percentages were arcsin-square-root-transformed to meet analysis assumptions (Sokal \& Rohlf 1987).

Quantifying influential factors. Model results were analyzed to determine whether environmental variability or larval swimming behavior had greater influence on spatial patterns of particle settlement. Connectivity matrices were created for each year and species. Each matrix $(2776 \times 2776)$ contained $(1)$ rows for each bar from which particles were released, (2) columns for each bar that particles encountered, and (3) elements containing the number of particles whose transit began and ended on each combination of release and stopping locations. To quantify the similarity between larval behaviors, every element of the Crassostrea virginica matrix was compared to the corresponding element of the $C$. ariakensis matrix from the same year using a Spearman rank-order correlation test $(\mathrm{n}=7706176)$, resulting in 5 correlation coefficients (one for each year). To quantify the similarity between environmental conditions, separate correlation analyses were conducted for the $C$. virginica and C. ariakensis matrices. Spearman rank-order correlation coefficients were calculated for each year compared to every other year (10 correlation coefficients were calculated for each species). A $t$-test was performed to determine if the means of the correlation coefficients for larval swimming behavior and environmental variability analyses were significantly different from each other (SAS ver 9.1).

\section{RESULTS}

Model results indicated that differences in physical conditions and larval swimming behavior affected particle trajectories. Crassostrea virginica and C. ariakensis particle distribution at the end of one simulation were clearly different (Fig. 4). Analysis of all scenarios demonstrated that the differences in larval swimming behaviors have the potential to influence dispersal distance, encounter with suitable habitat, and subpopulation connectivity.

Dispersal distance. Median dispersal distances differed significantly between species (Table 2, Fig. 5). The median dispersal distance of all particles in Chesapeake Bay during all years was $9.0 \mathrm{~km}$ for Crassostrea virginica and $7.1 \mathrm{~km}$ for $C$. ariakensis. While 


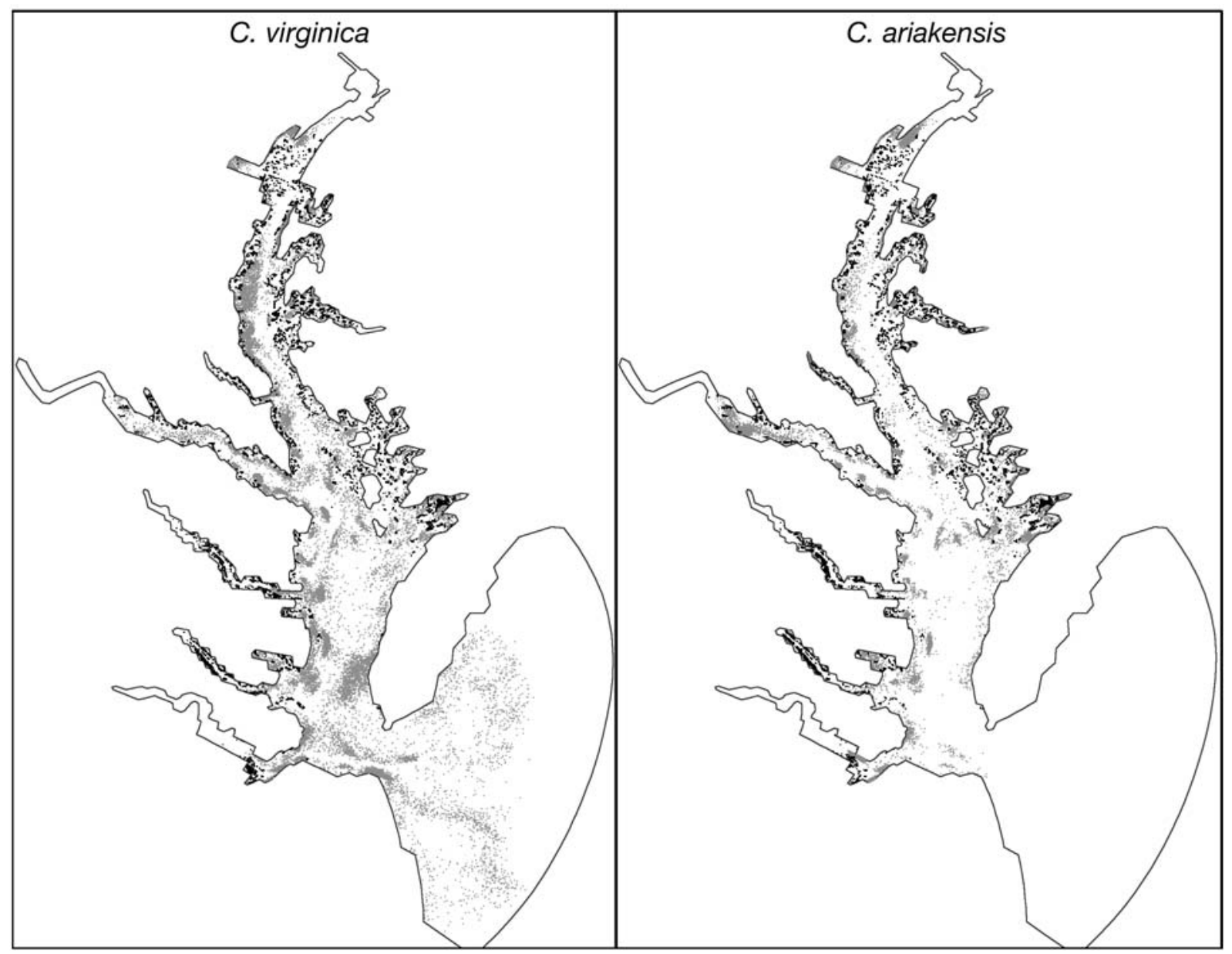

Fig. 4. End particle locations on July 16, 1995 for Crassostrea virginica (left), and C. ariakensis (right) simulations. Particles were released on June 23, 1995. Colors indicate whether particles encountered settlement habitat (black) or died (gray)

minimum dispersal distances were similar between species $(1 \mathrm{~m})$, the maximum dispersal distance of a $C$. virginica particle that encountered suitable habitat $(226.4 \mathrm{~km})$ was $\sim 100 \mathrm{~km}$ greater than that of a C. ariakensis particle $(121.4 \mathrm{~km})$.

Table 2. ANOVA tables from tests to determine if (A) median dispersal distance $(\mathrm{km})$, and $(\mathrm{B})$ transport success of particles differ between species, basins, and years. Effect: explanatory variables; Ndf: numerator degrees of freedom; Ddf: denominator degrees of freedom; $F$ : $F$-statistic; p: probability. $\mathrm{n}=140$ for each model

\begin{tabular}{|lcccr|}
\hline Effect & Ndf & Ddf & $F$ & \multicolumn{1}{c|}{$\mathrm{p}$} \\
\hline A. Median dispersal distance & $(\mathrm{km})$ & & \\
Species & 1 & 121 & 89.2 & $<0.0001$ \\
Basin & 13 & 121 & 57.4 & $<0.0001$ \\
Year & 4 & 121 & 2.1 & 0.09 \\
B. Transport success & & & & \\
Species & 1 & 121 & 5.3 & 0.02 \\
Basin & 13 & 121 & 45.0 & $<0.0001$ \\
Year & 4 & 121 & 0.2 & 0.94 \\
\hline
\end{tabular}

Median dispersal distance of settled particles differed significantly between basins (Table 2, Fig. 5). Crassostrea virginica particles released in the Maryland mainstem had the highest median dispersal distance $(20.5 \mathrm{~km})$ while those released in Piankatank River had the lowest $(3.6 \mathrm{~km})$. For C. ariakensis, highest median dispersal distances for all years occurred in the Maryland and Virginia mainstems $(14.0 \mathrm{~km})$ and the lowest was in the Piankatank River $(2.9 \mathrm{~km})$.

Within basins, interannual variability in median dispersal distances was observed (Fig. 5), especially for Crassostrea virginica particles. In the Maryland mainstem basin, median dispersal distances differed by as much as $15.9 \mathrm{~km}$ between years. This basin was strongly forced by the dominant Susquehanna River. Interannual variability in median dispersal distance was smaller for $C$. ariakensis particles (maximum = $3.7 \mathrm{~km}$ ) as expected based on their near-bottom location in the water column during the veliger and pediveliger stages. For several basins with high freshwater input, annual median dispersal distance of particles 

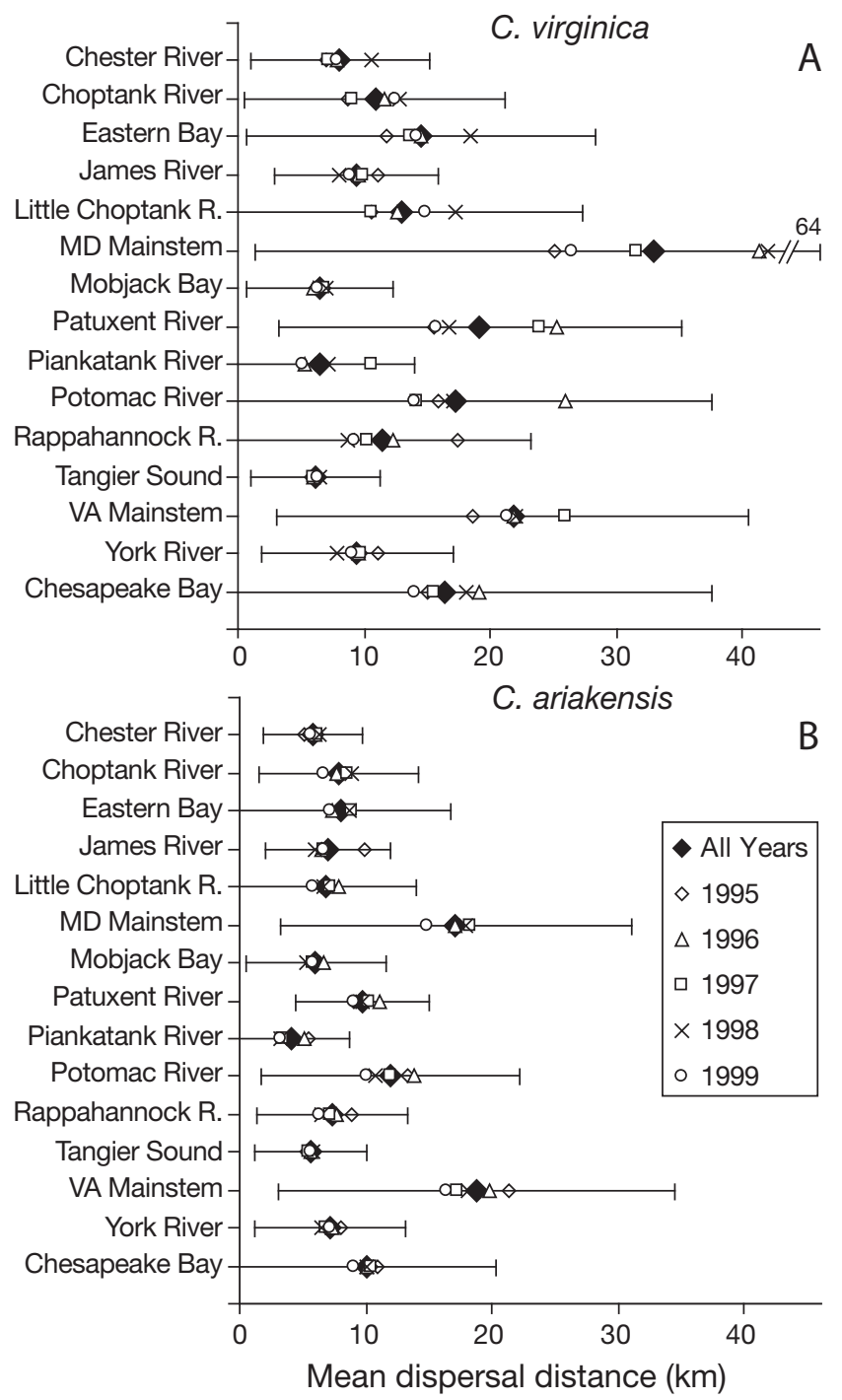

Fig. 5. Median dispersal distance (km) of (A) Crassostrea virginica, and (B) C. ariakensis successful particles released from within each basin and the entire Chesapeake Bay for each year. Dispersal distance was calculated as the shortest path between the release and ending locations within model boundaries. MD = Maryland, VA = Virginia. Symbols indicate median values. Horizontal lines represent the ranges between the median value and the 25 th and 75 th percentiles

was positively related to freshwater flow into the basin (Fig. 6). Despite the strong relationship between flow and dispersal in some basins, neither flow nor wind accounted for a significant amount of variability in median dispersal distance over the whole system (Table 3). Rather, regression results indicate that there was a significant negative relationship between habitat coverage in a basin and the dispersal distance of particles.

Transport success. Transport success differed significantly between species (Table 2, Fig. 7). Overall,
Crassostrea virginica particles had slightly lower transport success $(68 \%)$ than C. ariakensis particles $(74 \%)$. Few particles returned to the same bar on which they were released; overall self-recruitment scores were $2.4 \%$ for C. virginica and $3.4 \%$ for C. ariakensis (Table 4). For the entire Chesapeake system, annual $C$. ariakensis particle transport success was not related to freshwater flow during the time period of larval transport (Fig. 8). In contrast, there was a significant negative relationship ( $\alpha=0.05$, SAS ver 9.1) between annual transport success of $C$. virginica particles and freshwater flow into Chesapeake Bay during the time period of larval transport (Fig. 8). These findings are paralleled in the multiple regression analysis results based on basin-specific transport success values (Table 3).

Transport success of particles released within different basins differed significantly (Table 2), ranging from 12 to $90 \%$ (Crassostrea virginica particles) and

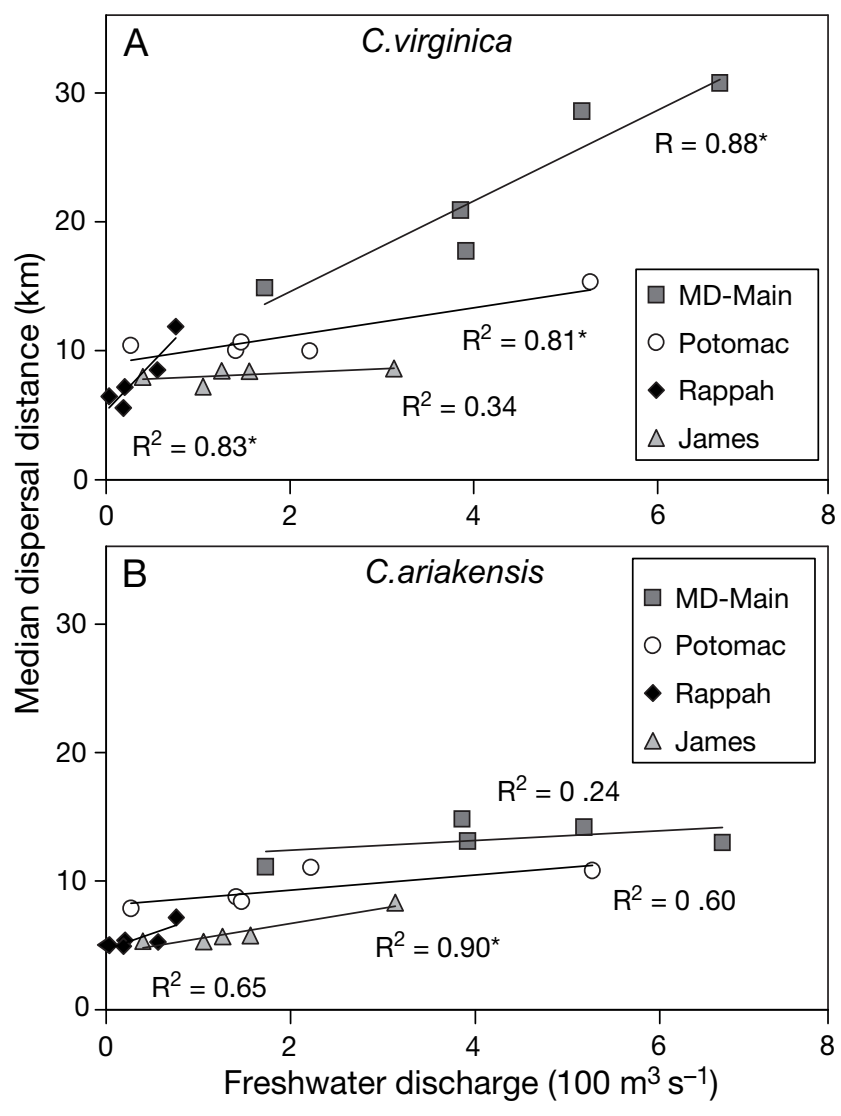

Fig. 6. Median dispersal distance $(\mathrm{km})$ of $(\mathrm{A}) \mathrm{C}$. virginica, and (B) C. ariakensis particles released from Maryland mainstem, Potomac, Rappahannock, and James River basins versus the mean of daily discharge for June, July and August from the Susquehanna, Potomac, Rappahannock, and James Rivers (1995 to 1999). An $\left(^{*}\right)$ after an $R^{2}$ value indicates that the slope of the regression line is significant $(\mathrm{n}=5, \alpha=0.05$, SAS ver 9.1) 
Table 3. Multiple regression tables for (A) median dispersal distance $(\mathrm{km})$, and (B) transport success of particles released from each basin in each year (1995 to 1999) for each species, showing parameter estimates (Param. Est.) for variables that accounted for a significant $(\alpha=0.05)$ amount of variability in dispersal distance or transport success. F: F-statistic; p: probability; ns: not significant; Effect: explanatory variables; Wind: the basin-specific indices for wind strength (mean of the summed magnitudes in the east and north directions); Flow: mean freshwater discharge into basins with freshwater forcing; and Habitat: habitat coverage (proportion of oyster habitat in basin). Basins without freshwater input in the hydrodynamic model were excluded from the analysis $(\mathrm{n}=40$ for each model)

\begin{tabular}{|lccc|}
\hline Effect & $F$ & $\mathrm{p}$ & Param. Est. \\
\hline A. Median dispersal distance $(\mathrm{km})$ & & \\
C. virginica & & & \\
Wind & 0.91 & 0.35 & $\mathrm{~ns}$ \\
Flow & 1.08 & 0.31 & $\mathrm{~ns}$ \\
Habitat & 4.97 & 0.03 & -0.08 \\
C. ariakensis & & & \\
Wind & 1.12 & 0.30 & $\mathrm{~ns}$ \\
Flow & 3.28 & 0.08 & $\mathrm{~ns}$ \\
Habitat & 16.83 & 0.0002 & -0.08 \\
B. Transport success & & & \\
C. virginica & & & \\
Wind & 1.31 & 0.26 & $\mathrm{~ns}$ \\
Flow & 8.66 & 0.01 & -0.000003 \\
Habitat & 37.74 & $<0.0001$ & 0.065 \\
C. ariakensis & & & \\
Wind & 0.03 & 0.86 & $\mathrm{~ns}$ \\
Flow & 0.04 & 0.85 & $\mathrm{~ns}$ \\
Habitat & 14.9 & 0.0005 & 0.071 \\
\hline
\end{tabular}

from 17 to $97 \%$ (C. ariakensis particles) (Fig. 7). For $C$. virginica, highest transport success occurred consistently in Eastern Bay and the Chester and Choptank Rivers. For C. ariakensis, highest transport success occurred in Eastern Bay and the Rappahannock and York Rivers. For both species, most of the variability in transport success was accounted for by habitat coverage in each basin (Table 3), indicating that the proportion of suitable oyster habitat in a basin positively influenced transport success.

Spatial patterns in source metrics were predicted for both Crassostrea virginica and $C$. ariakensis particles (Fig. 9, left panels). Overall spatial patterns were similar between species: Eastern shore tributaries in Maryland, Tangier Sounds, and western shore tributaries in Virginia contained high numbers of bars from which $>80 \%$ of the particles that were released from the bar were able to encounter suitable habitat. Betweenspecies differences existed, with higher scores for $C$. ariakensis particles than $C$. virginica particles in the Maryland mainstem but lower scores for C. ariakensis particles in the upper reaches of some tributaries (e.g. Choptank and Patuxent Rivers).
Spatial patterns in transport sink metrics for each bar were not as coherent as source metrics predicted (Fig. 9, right panels). There was a marked difference between species in the spatial distribution of bars on which $>700 \%$ more particles encountered the bar than were released from it. These bars occurred in the mainstem and downstream of major source basins for Crassostrea virginica, whereas they tended to occur near the heads of tributaries for $C$. ariakensis.

Based on model simulations from all years, most successful particles of both species encountered habitat within the basin in which they were released, except for Crassostrea virginica in the Little Choptank (shaded elements in Tables 5 \& 6). Crassostrea virginica particle 'populations' had higher connectivity with surrounding basins: The average percent of $C$. virginica particles that did not encounter habitat in the basin in which they were released was $20 \%$, compared to $10 \%$ for $C$. ariakensis. In addition, the difference in swimming behavior resulted in a significant difference in the number of connections between basins (paired $t$-test, $\mathrm{p}=0.001, \mathrm{n}=14, \mathrm{SAS}$ ver 9.1): The mean number of connections between basins for $C$. virginica larvae was 6 whereas the mean number for $C$. ariakensis was 3.

Quantifying influential factors. Correlation analyses indicated that, in the absence of egg production and larval mortality, larval swimming behavior had greater influence on the spatial trajectories of particles than variability in circulation patterns stemming from interannual differences in flow and wind. Mean correlation coefficients for comparisons between connectivity matrices from models with different circulation patterns but the same larval behavior (Crassostrea virginica: $0.43 \pm 0.005 \mathrm{SE}$, and C. ariakensis: $0.47 \pm$ $0.006 \mathrm{SE})$ were significantly higher $(t$-test, $\mathrm{p}<0.0001)$ than those from models with different larval behaviors but the same physical forcing $(0.32 \pm 0.009 \mathrm{SE})$.

\section{DISCUSSION}

Model results indicated that even simple differences in oyster larvae swimming behaviors could have significant consequences for dispersal-related processes in Chesapeake Bay. Simulated larval swimming behavior influenced dispersal distances, temporal and spatial patterns in transport success, self-recruitment, the degree of connectivity between basins, and sourcesink characteristics of bars. Results support studies and synthesis papers that indicate that vertical swimming behavior is an important factor that influences oyster larvae vertical distributions and transport (Mann 1988, Jacobsen et al. 1990, Dekshenieks et al. 1996, Kennedy 1996, Newell et al. 2005, J. L. Manuel et al. unpubl.). 


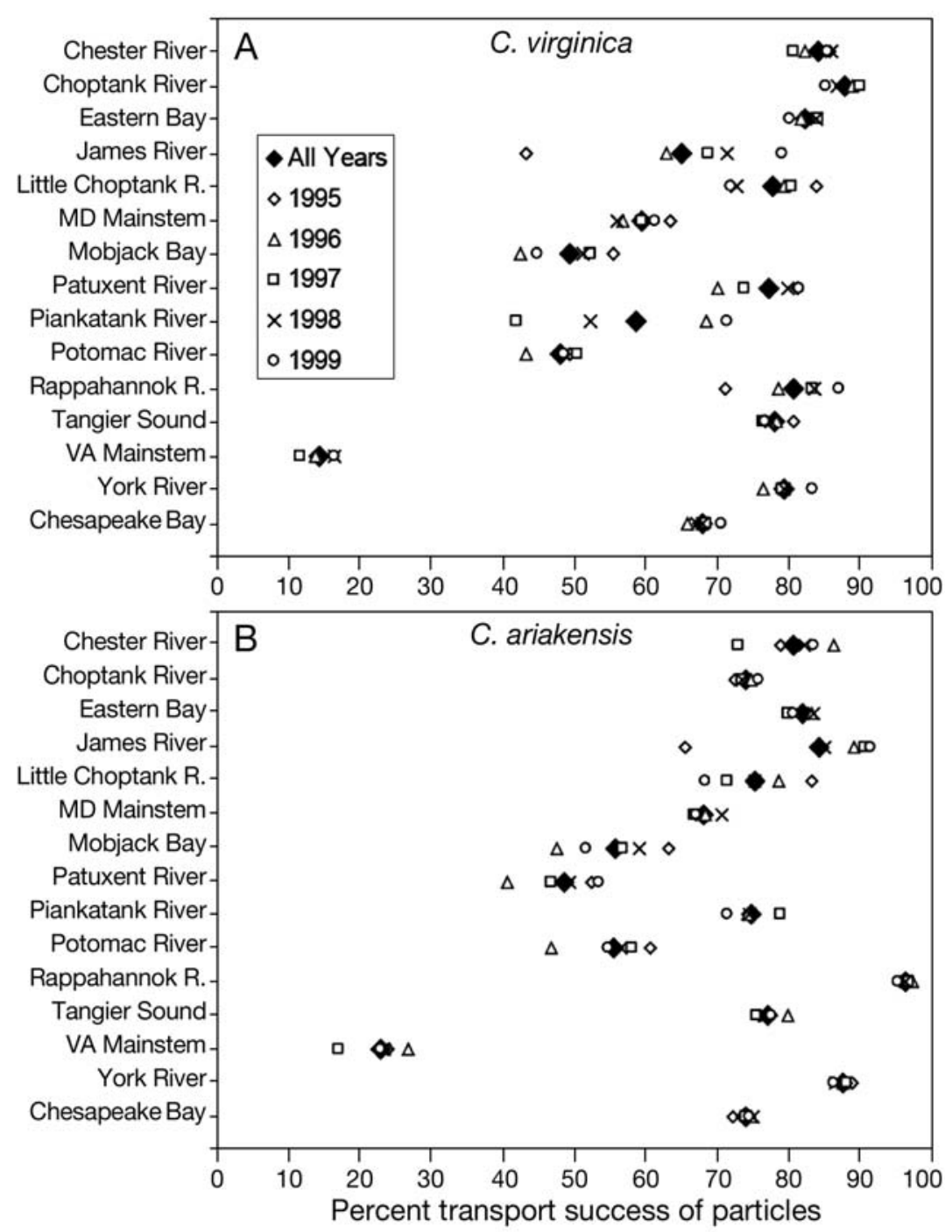

Fig. 7. Percent transport success of (A) Crassostrea virginica, and (B) C. ariakensis particles for each year and for all years, and for each basin and the entire Chesapeake Bay. Percentages were calculated as the number of particles that were released from the basin and encountered suitable habitat divided by the number of particles released in the basin. $\mathrm{MD}=$ Maryland, VA $=$ Virginia

Table 4. Self-recruitment scores for Crassostrea virginica and C. ariakensis particles (number and percent of particles that returned to the same bar from which they were released)

\begin{tabular}{|c|c|c|c|c|c|}
\hline \multirow[t]{2}{*}{ Year } & \multirow{2}{*}{$\begin{array}{c}\text { Total } \\
\text { released } \\
\text { per species }\end{array}$} & \multicolumn{2}{|c|}{$\begin{array}{c}\text { C. virginica } \\
\text { returned }\end{array}$} & \multicolumn{2}{|c|}{$\begin{array}{l}\text { C. ariakensis } \\
\text { returned }\end{array}$} \\
\hline & & No. & $\%$ & No. & $\%$ \\
\hline 1995 & 313865 & 7927 & $2.5 \%$ & 10172 & $3.2 \%$ \\
\hline 1996 & 313865 & 6642 & $2.1 \%$ & 10729 & $3.4 \%$ \\
\hline 1997 & 313865 & 7397 & $2.4 \%$ & 9998 & $3.2 \%$ \\
\hline 1998 & 313865 & 6635 & $2.1 \%$ & 10186 & $3.2 \%$ \\
\hline 1999 & 313865 & 8563 & $2.7 \%$ & 11973 & $3.8 \%$ \\
\hline 1995-1999 & 1569325 & 37164 & $2.4 \%$ & 53058 & $3.4 \%$ \\
\hline
\end{tabular}

The finding that larval swimming behavior had a stronger influence on the trajectories of particles than interannual variability in environmental conditions is significant. This indicates that larval swimming behavior should be considered in field and modeling studies as well as in management applications that incorporate larval transport (e.g. design of marine protected areas).

It is important to keep in mind the limitations and utility of this numerical study. This modeling effort could be limited by lack of complexity, both in terms of the physical and biological models. Although state-of-the-art, the hydrodynamic model did not include water depths $<2 \mathrm{~m}$, small sub-tributaries in which oysters reside, and the full length of all tributaries to the head of tide. The influence of processes that occur outside the model domain such as settlement on reefs that were not simulated or transport of particles beyond model boundaries limits the inference of the model; The influence of these constraints on model predictions remains to be assessed. In addition, the biological model did not include the complexities of Crassostrea spp. behaviors (J. L. Manuel et al. unpubl.) nor a sophisticated near-bed larval settlement model (Gross et al. 1992). Population-specific differences in larval behaviors have been identified in other bivalve species (e.g. Manuel et al. 1996), yet our behavior model assumed a single species-specific swimming behavior for all sub-populations in Chesapeake Bay and included only one of many possible factors that could influence larval vertical migrations (the response to a halocline). Again, the influence of these constraints on model predictions remains to be assessed, although simulations that quantify the influence of behavioral complexity on larval dispersal are planned.

The model does not include biological factors that influence population dynamics like gamete production, larval growth, and larval mortality. These factors were held constant because the purpose of this analysis was to isolate and quantify the influence of circula- 


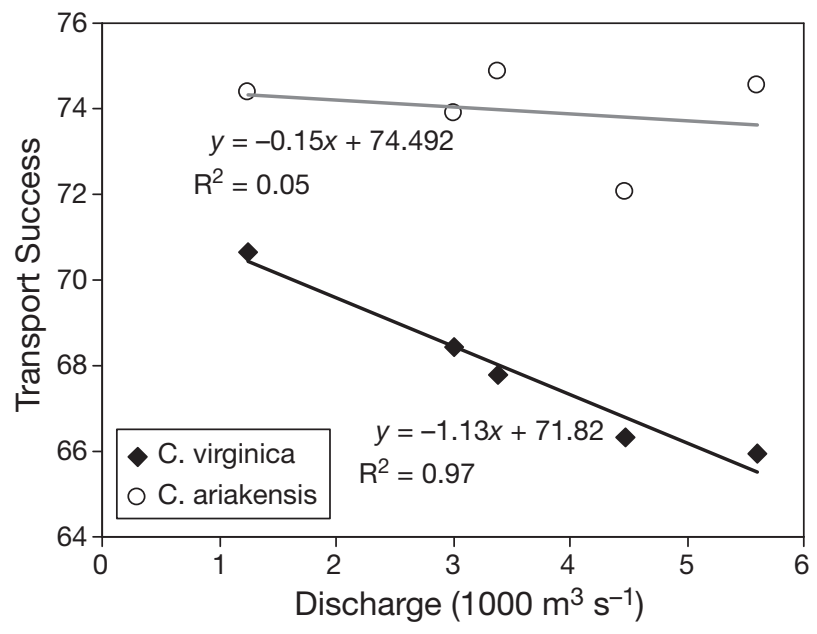

Fig. 8. Transport success of Crassostrea virginica and C. ariakensis in each year versus freshwater discharge into Chesapeake Bay during June to August (1995 to 1999). The slope of the $C$. virginica regression was significant $(\mathrm{p}=0.003, \mathrm{n}=5$, SAS ver 9.1). The slope of $C$. ariakensis regression line was not significant $(\alpha=0.05)$

tion, larval swimming behavior, and habitat location on the dispersal of larvae and on their encounter with suitable settlement habitat. This analysis can be regarded as the first step in a systematic effort to partition mortality by quantifying one of many factors that influence survival of oyster larvae.

Despite the simplification of biological dynamics and estuarine systems, the model predictions do increase our understanding of how physical-biological interactions during the early life of organisms could influence population dispersal. For example, model results indicate that the combination of estuarine circulation patterns and differences in larval swimming behavior resulted in different dispersal and settlement patterns. Crassostrea virginica veliger particles remained in the upper layer where net flow was down-estuary, and wind and freshwater flow events had a strong effect on transport. Crassostrea ariakensis particles had lower dispersal distances; veliger particles tended to remain in the lower layer where the influence of flow and wind events was not as direct, net circulation was up-estuary, and friction reduced transport of particles near bottom. The species-specific relationships between total transport success in Chesapeake Bay and freshwater flow (Fig. 8) reflect these differences. Annual $C$. ariakensis transport success was not related to freshwater flow during the time period of larval transport. In contrast, there was a significant negative relationship between annual transport success of $C$. virginica and freshwater flow during the time period of larval transport, a pattern that has been observed for C. virginica juvenile populations in the upper Chesapeake Bay
(Ulanowicz et al. 1980, Kimmel \& Newell 2007, Vølstad et al. 2008). The positive relationship between freshwater flow and dispersal distance suggests that a portion of the observed mortality associated with high flow years could be due to down-estuary transport of larvae into the mainstem Bay where oyster habitat coverage is low.

Results suggest that some basins could have more consistent settlement than others due to available habitat in a basin and the circulation patterns within it. Transport success of any given particle was influenced by (1) the proportion of suitable habitat within a basin, (2) the shape of the basin in which it was released (because basin shape influenced circulation patterns within the basin), and (3) inter-annual differences in flow and wind. That some basins have enhanced 'trapping' ability for oyster larvae has been observed in small sub-tributaries of Chesapeake Bay (Manning \& Whaley 1955, Kennedy 1980, Boicourt 1982, Andrews 1983). Model results suggest that 'trapping' circulation patterns may also be present in larger tributary systems as suggested by Rose et al. (2006).

Model results can be used to quantify larval mortality that results from the combination of advective processes and distribution of settlement habitat. Annual particle transport success was relatively constant for the entire Chesapeake system (66 to $71 \%$ for Crassostrea virginica and 72 to $75 \%$ for C. ariakensis, Fig. 7). The high overall transport success in the entire basin likely occurs because the residence time of water in the bay ( 17 to $42 \mathrm{wk}_{\text {; }}$ Shen \& Wang 2007) is much longer than the duration of particle transport in the model $(\sim 3 \mathrm{wk})$; Therefore most particles remained within the system where simulated habitat was located. In addition, tidal advection combined with a pediveliger stage duration of $\sim 1$ wk gave particles multiple opportunities to encounter suitable habitat, potentially reducing variability in particle transport success (but not dispersal distance). The percentage of unsuccessful particles suggests that $\sim 32 \%$ of $C$. virginica larval mortality in the entire bay could result from the inability of larvae to encounter suitable settlement habitat within the estuary. Because larval plank-

Fig. 9. Source and sink scores for individual oyster bars based on all model simulations (1995 to 1999) for Crassostrea virginica (top panels), and C. ariakensis (bottom panels) larval behaviors. Source bars (left panels) are color coded according to the percentage of particles released from the bar that encountered settlement habitat. Sink bars (right panels) are color coded according to the percentage of particles that encountered the bar per number of successful particles that were released from the bar 

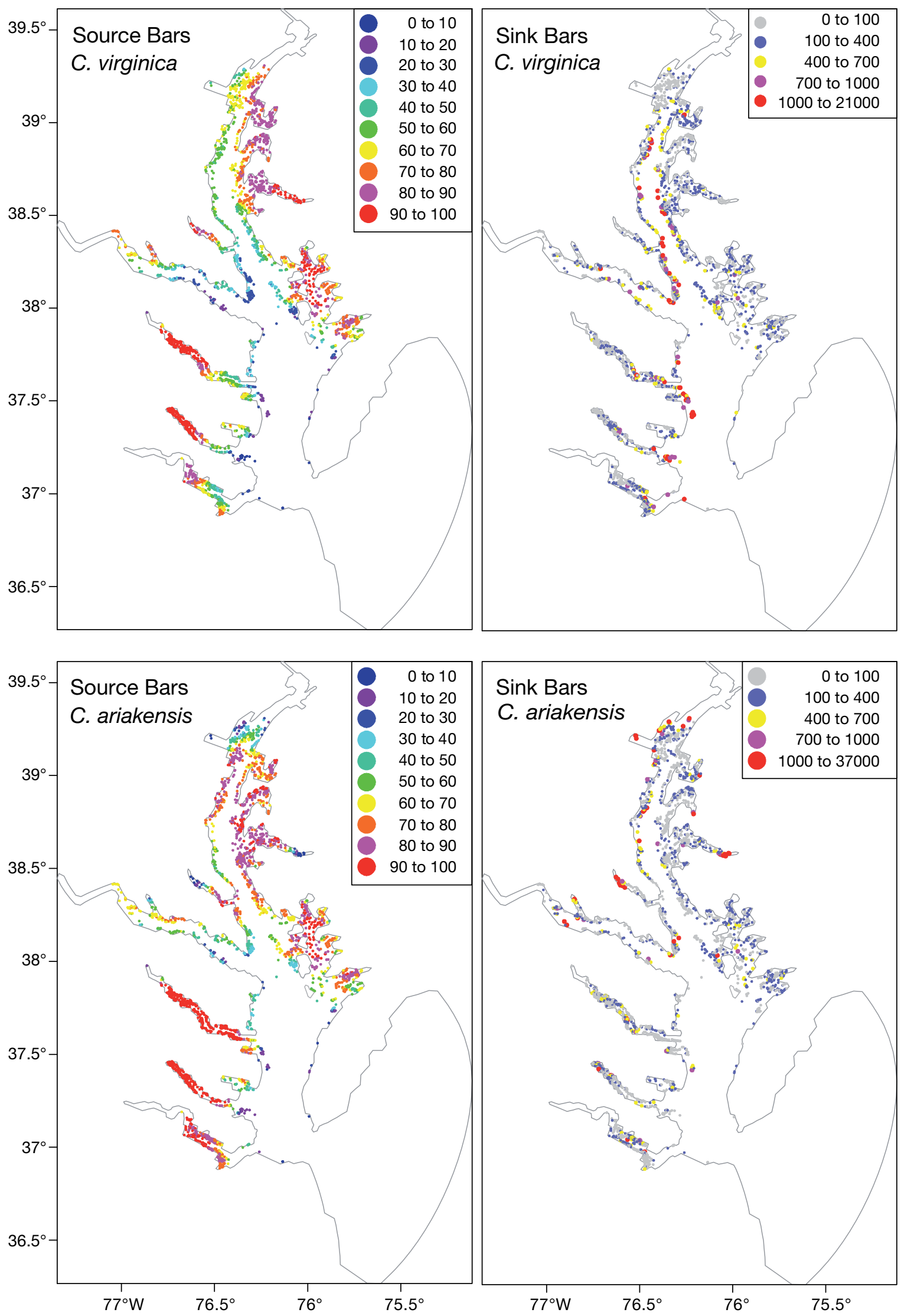


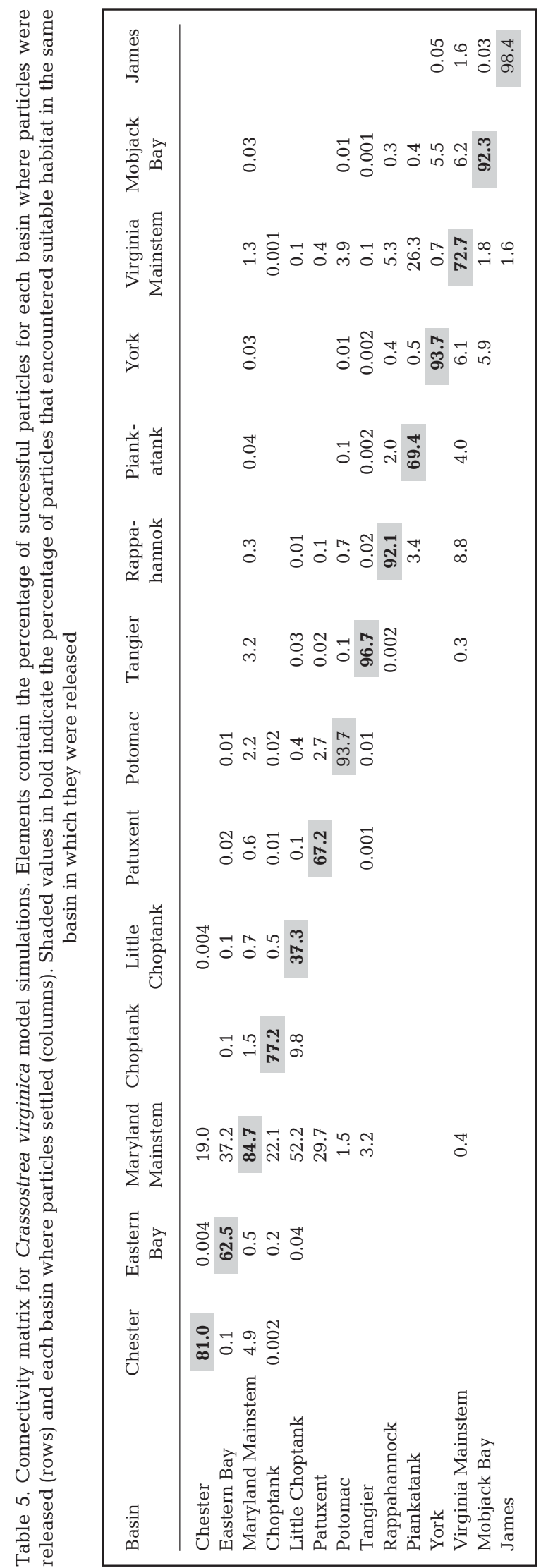

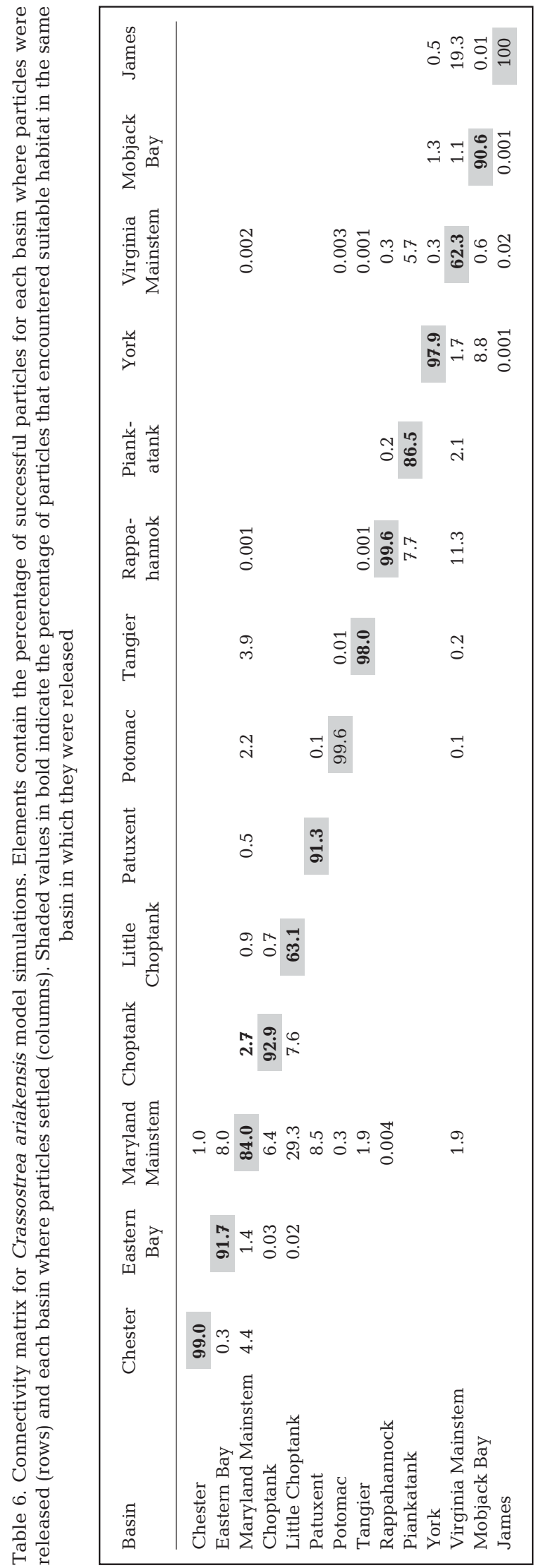


tonic organisms that spend 14 to $25 \mathrm{~d}$ in the water column suffer 95 to $99 \%$ mortality (calculation based on Table 1 of Eckman 1996), most oyster larvae mortality (63 to $67 \%$ ) is likely related to important processes that are not parameterized in the larval transport model, such as starvation, predation (Dekshenieks et al. 1997), and salinity- and temperature-dependent mortality (Lough 1975). Although Bay-wide particle transport success was relatively constant, basin-specific transport success differed greatly, and in some basins, differed between years. This indicates that advective losses are potentially a larger source of $C$. virginica larval mortality in some basins (e.g. Virginia mainstem, Potomac River, Mobjack Bay) compared to others, and are likely a function of the area and location of suitable settlement habitat within and down-estuary of the basin.

The differences in connectivity between simulated Crassostrea virginica and C. ariakensis subpopulations have important implications for the rate of spread of restored or introduced populations as well as their capacity to exchange genetic information throughout the large Chesapeake system. Rose et al. (2006) examined genetic spatial population structures of $C$. virginica in Chesapeake Bay using 8 microsatellite loci. They found significant levels of geographic differentiation overall as well as a subtle pattern of isolation by distance. Our model results indicate that northern Bay C. virginica populations (e.g. Chester, Choptank Rivers) are at least one generation removed from southern Bay populations (e.g. James, York Rivers) because particles were not exchanged between these basins. This provides at least one mechanism that could contribute to the isolation by distance observed by Rose et al. (2006). Model results also suggest that $C$. ariakensis behavior would promote greater genetic isolation by distance than that of $C$. virginica.

Model predictions should be applied at a scale commensurate with model formulation and resolution. For example, results should not be used as evidence to suggest that Crassostrea ariakensis would remain within Chesapeake Bay if introduced into that system. The model was not designed to address coastal dispersal potential. Also, the hydrodynamic grid resolution constrains the applicability of model results. Higher resolution hydrodynamic models with nested or unstructured grids would be required to refine circulation predictions within tributaries to guide the location of specific oyster restoration sites. Finally, the slightly higher overall transport success of $C$. ariakensis (74\%) versus C. virginica (68\%) particles does not indicate that $C$. ariakensis larvae would have higher survival than $C$. virginica in Chesapeake Bay. Factors that would be necessary to evaluate survival were not parameterized in the model, such as species-specific salinity-dependent mortality and predation on newly settled larvae (Newell et al. 2000).

This study is a first step toward partitioning spatially dependent factors that influence variations in oyster recruitment. The model cannot reproduce the ordersof-magnitude variability that is inherent in oyster recruitment because it does not include many important nonlinear biological processes such as adult spawner abundances, gamete fertilization success, and larval and juvenile mortality and growth (Kennedy 1996). Future analyses will build upon these results by systematically assessing the potential contribution of adult production, larval growth and mortality to oyster recruitment variability. Preliminary links of larval transport with a juvenile-adult demographic model (Vølstad et al. 2006) suggest that the addition of biological factors is critical for predicting juvenile oyster recruitment (North et al. 2006c), a finding similar to that of Mann \& Evans (1998).

Model results have implications for fisheries management and oyster restoration programs. Few particles returned to the same bar on which they were released $\left(<4 \% \mathrm{yr}^{-1}\right)$, indicating that oyster subpopulations span multiple bars and that restoration efforts of isolated bars may not be as successful as those within networks of settlement habitat. There were speciesspecific spatial patterns in the source and sink characteristics of individual oyster bars, suggesting that placement of spawning stock sanctuaries and harvesting areas could be optimized to promote reproductive success of the population and minimize harvest impacts on the spawning stock. The differences in spatial patterns also indicate that the 2 species could respond differently to the same fishing effort and sanctuary placement such that species-specific management strategies could be required. Although results indicate that spatial patterns likely exist, the model does not predict actual spatial patterns because important biological processes (e.g. egg production, larval growth and mortality) were absent from the model. Larval transport models with enhanced production and mortality algorithms, or links with demographic models, could be used to help guide oyster restoration activities by predicting optimum locations for spawning stock sanctuaries or for harvest.

Acknowledgements. We thank M. Christman, K. Greenhawk, M. Hare, B. Hilderbrand, T. Lookingbill, J. Manuel, R. Newell, and J. Vølstad for their helpful discussions and contributions. We appreciate the constructive suggestions provided by the anonymous reviewers. This research was supported by the Maryland Department of Natural Resources (K00P4200981), the National Science Foundation Biological Oceanography Program (OCE-0424932), and NOAA Chesapeake Bay Studies (NA04NMF4570389). This is UMCES-HPL contribution \#4170. 


\section{LITERATURE CITED}

Andrews JD (1983) Transport of bivalve larvae in James River, Virginia. J Shellfish Res 3:29-40

Baker P (2003) Two species of oyster larvae show different depth distributions in a shallow, well-mixed estuary. J Shellfish Res 22:733-736

Batchelder HP (2006) Forward-in-time-/backward-in-timetrajectory (FITT/BITT) modeling of particles and organisms in the coastal ocean. J Atmos Ocean Technol 23: 727-741

Boicourt WC (1982) Estuarine larval retention mechanisms on two scales. In: Kennedy VS (ed) Estuarine comparisons. Academic Press, New York, p 445-457

Boicourt WC (1992) Influences of circulation processes on dissolved oxygen in the Chesapeake Bay. In: Smith DE, Leffler M, Mackiernan G (eds) Oxygen dynamics in the Chesapeake Bay: a synthesis of recent research. Maryland Sea Grant Publication, College Park, MD, p 7-59

Breese WP, Malouf RE (1977) Hatchery rearing techniques for the oyster Crassostrea rivularis Gould. Aquaculture 12: 123-126

> Carriker MR (1951) Ecological observations on the distribution of oyster larvae in New Jersey estuaries. Ecol Monogr 21:19-38

Carriker MR (1996) The shell and ligament. In: Kennedy VS, Newell RIE, Eble AF (eds) The Eastern Oyster Crassostrea virginica. Maryland Sea Grant Publication, College Park, MD, p 75-168

Chesapeake Bay Program (2000) Chesapeake 2000 Agreement. Chesapeake Bay Program. www.chesapeakebay. net/agreement.htm

Cowen RK, Paris CB, Srinivasan A (2006) Scaling of connectivity in marine populations. Science 311:522-527

Dekshenieks MM, Hofmann EE, Klinck JM, Powell EN (1996) Modeling the vertical distribution of oyster larvae in response to environmental conditions. Mar Ecol Prog Ser 136:97-110

- Dekshenieks MM, Hofmann EE, Klinck JM, Powell EN (1997) A modeling study of the effects of size- and depth-dependent predation on larval survival. J Plankton Res 19: 1583-1598

Dippner JW (2004) Mathematical modeling of the transport of pollution in water. In: Filar JA, Krawczyk JB (eds) Encyclopedia of Life Support Systems (EOLSS). Eolss Publishers, Oxford

Eckman JE (1996) Closing the larval loop: linking larval ecology to the population dynamics of marine benthic invertebrates. J Exp Mar Biol Ecol 200:207-237

Finelli CM, Wethey DS (2003) Behavior of oyster (Crassostrea virginica) larvae in flume boundary layer flows. Mar Biol 143:703-711

Genin A, Jaffe JS, Reef R, Richter C, Franks PJS (2005) Swimming against the flow: a mechanism of zooplankton aggregation. Science 308:860-862

Greenhawk K (2005) Development of a potential habitat layer for Maryland oyster bottom. Maryland Department of Natural Resources, Fisheries Division, Annapolis, MD

Gross TF, Werner FE, Eckman JE (1992) Numerical modeling of larval settlement in turbulent bottom boundary layers. J Mar Res 50:611-642

> Hidu H, Haskin HH (1978) Swimming speeds of oyster larvae Crassostrea virginica in different salinities and temperatures. Estuaries 1:252-255

Hofmann EE, Powell EN, Bochenek EA, Klinck JM (2004) A modeling study of the influence of environment and food supply on survival of Crassostrea gigas larvae. ICES J Mar
Sci 61:596-616

Hunter J, Craig P, Phillips H (1993) On the use of randomwalk models with spatially variable diffusivity. J Comput Phys 106:366-376

Jacobsen TR, Milutinovic JD, Miller JR (1990) Observational and model studies of physical processes affecting benthic larval recruitment in Delaware Bay. J Geophys Res 95: 20331-20345

Jordan SJ, Greenhawk KN, McCollough CB, Vanisko J, Homer ML (2002) Oyster biomass, abundance, and harvest in northern Chesapeake Bay: trends and forecasts. J Shellfish Res 21:733-741

Kennedy VS (1980) Comparison of recent and past patterns of oyster settlement and seasonal fouling in Broad Creek and Tred Avon River, Maryland. Proc Natl Shellfish Assoc 70: $36-46$

Kennedy VS (1991) Eastern oyster Crassostrea virginica. In: Funderburk SL, Jordan SJ, Mihursky JA, Riley D (eds) Habitat Requirements for Chesapeake Bay Living Resources. Chesapeake Bay Program, Annapolis, MD, p 3.1-3.20

Kennedy VS (1996) Biology of larvae and spat. In: Kennedy VS, Newell RIE, Eble AF (eds) The Eastern Oyster Crassostrea virginica. Maryland Sea Grant Publication, College Park, MD, p 371-421

Kimmel DG, Newell RIE (2007) Climate drives variability of eastern oyster (Crassostrea virginica) recruitment in Chesapeake Bay. Limnol Oceanogr 52:959-965

- Knights AM, Crowe TP, Burnell G (2006) Mechanisms of larval transport: Vertical distribution of bivalve larvae varies with tidal conditions. Mar Ecol Prog Ser 326:167-174

- Leis JM (2007) Behaviour as input for modelling dispersal of fish larvae: behaviour, biogeography, hydrodynamics, ontogeny, physiology and phylogeny meet hydrography. Mar Ecol Prog Ser 347:185-193

Li M, Zhong L, Boicourt WC (2005) Simulations of Chesapeake Bay estuary: sensitivity to turbulence mixing parameterizations and comparison with observations. J Geophys Res 110(C12004) doi:10.1029/2004JC002585

Li M, Zhong L, Boicourt WC, Zhang S, Zhang DL (2006) Hurricane-induced storm surges, currents and destratification in a semi-enclosed bay. Geophys Res Lett 33(L02604) doi:10.1029/2005GL024992

Li M, Zhong L, Boicourt WC, Zhang DL (2007) Hurricaneinduced destratification and restratification in a partially mixed estuary. J Mar Res 65:169-192

Lough RG (1975) A reevaluation of the combined effects of temperature and salinity on survival and growth of bivalve larvae using response surface techniques. Fish Bull 73:86-94

Luckenbach M, Tamburri M, Breitburg D (2005) Behavior and substrate selection in $C$. ariakensis pediveliger larvae in response to variation in environmental condition. Final Report to Maryland Department of Natural Resources, Annapolis, MD, May 16, 2005

Mann R (1988) Distribution of bivalve larvae at a frontal system in the James River, Virginia. Mar Ecol Prog Ser 50:29-44

Mann R, Evans DA (1998) Estimation of oyster Crassostrea virginica standing stock, larval production and advective loss in relation to observed recruitment in the James River, Virginia. J Shellfish Res 17:239-253

Mann R, Rainer JS (1990) Effect of decreasing oxygen tension on swimming rate of Crassostrea virginica (Gmelin, 1791) larvae. J Shellfish Res 9:323-327

Mann R, Campos BM, Luckenbach MW (1991) Swimming rate and responses of larvae of three mactrid bivalves to salinity discontinuities. Mar Ecol Prog Ser 68:257-269 
Manning JH, Whaley HH (1955) Distribution of oyster larvae and spat in relation to some environmental factors in a tidal estuary. Proc Natl Shellfish Assoc 45:56-65

Manuel JL, Gallager SM, Pearce CM, Manning DA, O'Dor RK (1996) Veligers from different populations of sea scallop Placopecten magellanicus have different vertical migration patterns. Mar Ecol Prog Ser 142:147-163

Nelson TC, Perkins EB (1932) Report of the Department of Biology 1931. New Jersey State Agricultural Experiment Station, New Brunswick, NJ, p 111-122

Newell RIE, Alspach GS, Kennedy VS, Jacobs D (2000) Mortality of newly metamorphosed eastern oysters (Crassostrea virginica) in mesohaline Chesapeake Bay. Mar Biol 136:665-676

Newell RIE, Kennedy VS, Manuel JL, Meritt D (2005) Behavioral responses of Crassostrea ariakensis and Crassostrea virginica larvae to environmental change under spatially realistic conditions. Final Report to Maryland Department of Natural Resources, Annapolis, MD, 28 p

North EW, Hood RR, Chao SY, Sanford LP (2006a) Using a random displacement model to simulate turbulent particle motion in a baroclinic frontal zone: A new implementation scheme and model performance tests. J Mar Syst 60: 365-380

North EW, Schlag Z, Hood RR, Zhong L, Li M, Gross T (2006b) Modeling dispersal of Crassostrea ariakensis oyster larvae in Chesapeake Bay. Maryland Department of Natural Resources, 55 pNorth EW, Vølstad J, Christman M, Hood RR and others (2006c) Linking larval transport and fisheries demographic models to study the influence of environmental variability and larval behavior on juvenile recruitment to oyster populations. ICES CM 2006 O:13, $13 \mathrm{p}$

Pritchard DW (1952) Salinity distribution and circulation in the Chesapeake Bay estuarine system. J Mar Res 11: 106-123

Pulliam HR (1988) Sources, sinks, and population regulation. Am Nat 132:652-661

Rose CG, Paynter KT, Hare MP (2006) Isolation by distance in the eastern oyster Crassostrea virginica in Chesapeake Bay. J Hered 97:158-170

Rothschild BJ, Ault JS, Goulletquer P, Heral M (1994) Decline of the Chesapeake Bay oyster population - a century of habitat destruction and overfishing. Mar Ecol Prog Ser 111:29-39

Schubel JR, Pritchard DW (1987) A brief physical description of the Chesapeake Bay. In: Majumdar SK, Hall LW, Jr., Adams HM (eds) Contaminant problems and management of living Chesapeake Bay resources. The Pennsylvania Academy of Science, Easton, PA, p 1-32

Shanks AL, Brink L (2005) Upwelling, downwelling, and cross-shelf transport of bivalve larvae: test of a hypothesis. Mar Ecol Prog Ser 302:1-12

Shen J, Wang HV (2007) Determining the age of water and long-term transport timescale of the Chesapeake Bay. Estuar Coast Shelf Sci 74:585-598

Shumway SE (1996) Natural environmental factors. In:

Editorial responsibility: Howard Browman,

Storebø, Norway
Kennedy VS, Newell RIE, Eble AF (eds) The Eastern Oyster Crassostrea virginica. Maryland Sea Grant Publication, College Park, MD, p 467-513

Smith GF, Bruce DG, Roach EB, Hansen A, Newell RIE, McManus AM (2005) Assessment of recent habitat conditions of eastern oyster Crassostrea virginica bars in mesohaline Chesapeake Bay. N Am J Fish Manage 25: 1569-1590

Sokal RR, Rohlf FJ (1987) Introduction to biostatistics. W. H. Freeman \& Co., New York

Song YH, Haidvogel D (1994) A semi-implicit ocean circulation model using a generalized topography-following coordinate system. J Comput Phys 115:228-244

Southworth M, Harding JM, Mann R (2003) The status of Virginia's public oyster resource 2003. Molluscan Ecology Program, Virginia Institute of Marine Science, The College of William and Mary, Gloucester Point, VA

Tamburri MN, Finelli CM, Wethey DS, Zimmer-Faust RK (1996) Chemical induction of larval settlement behavior in flow. Biol Bull 191:367-373

Thompson RJ, Newell RIE, Kennedy VS, Mann R (1996) Reproductive processes and early development. In: Kennedy VS, Newell RIE, Eble AF (eds) The Eastern Oyster Crassostrea virginica. Maryland Sea Grant Publication, College Park, MD, p 335-370

Turner EJ, Zimmer-Faust RK, Palmer MA, Luckenbach M, Pentchef ND (1994) Settlement of oyster (Crassostrea virginica) larvae: effects of water flow and a water soluble chemical cue. Limnol Oceanogr 39:1579-1593

Ulanowicz RE, Caplins WC, Dunnington EA (1980) The forecasting of oyster harvest in central Chesapeake Bay. Estuar Coast Mar Sci 11:101-106

USACOE (2004) Notice of intent to prepare an environmental impact statement for the proposed introduction of the oyster species Crassostrea ariakensis. In: Army DoT (ed) Federal Register, DOCID:fr05ja04-45, wais.access.gpo.gov, p 330-332

Visser AW (1997) Using random walk models to simulate the vertical distribution of particles in a turbulent water column. Mar Ecol Prog Ser 158:275-281

Vølstad JH, Christman M, Lewis D, Dew J (2006) Modeling population growth and dynamics of oysters in the Chesapeake Bay under different management scenarios. Report to Maryland Department of Natural Resources, Annapolis, MD

Vølstad JH, Dew J, Tarnowski M (2008) Estimation of annual mortality rates for eastern oysters (Crassostrea virginica) in Chesapeake Bay based on box counts, and application of those rates for projection of population growth of $C$. virginica and C. ariakensis. J Shellfish Res 27: in press

> Wang DP (1979) Subtidal sea level variations in the Chesapeake Bay and relations to atmospheric forcing. J Phys Oceanogr 9:413-421

> Warner JC, Geyer WR, Lerczak JA (2005) Numerical modeling of an estuary: a comprehensive skill assessment. J Geophys Res 110(C05001)

Zhong L, Li M (2006) Tidal energy fluxes and dissipation in the Chesapeake Bay. Cont Shelf Res 26:752-770

Submitted: February 6, 2007; Accepted: October 31, 2007

Proofs received from author(s): March 29, 2008 